\title{
PERSPECTIVE
}

\section{Parental smartphone use and children's mental outcomes: a neuroscience perspective}

\author{
Tallie Z. Baram ${ }^{1,2,3}$ and Jessica L. Bolton ${ }^{1,2}$ \\ Neuropsychopharmacology (2019) 44:239-240; https://doi.org/10.1038/s41386-018-0184-8
}

Cellphone/smartphone use is now constant and ubiquitous: over $95 \%$ of millennials and $85 \%$ of Gen-X individuals own a smartphone, and many are online constantly [1, 2]. These individuals are current and future parents, and their device use throughout the day overlaps their interactions with their infants and children. What (if any), are the consequences of parental smartphone use on infants' brain development? How might smartphone use by a parent influence the maturation of the cognitive, emotional and social brain?

An early concern was the potential effect of prenatal and postnatal exposure to cell-phone related electromagnetic fields (EMF) on behavioral (cognitive, emotional) outcomes in children [3]. Whereas this topic aroused prominent public concern, the effects reported by controlled studies were small, and accounting for numerous potential confounders as well as establishing causality was difficult. A related worry, shown to be unfounded, was potential EMF-related hearing loss [4].

Whereas concerns related to the physical properties of cellphones have not been significantly substantiated, a key ongoing question is whether intermittent, unpredictable distraction of a parent as a result of messages, tweets, posts, news, and shows might interfere with parent-infant interactions in a manner that leaves a persistent mark on brain maturation. This is a real and pressing question because, over the past century, hundreds of investigations worldwide have clearly demonstrated the crucial role of signals from the primary caretaker in modulating the cognitive and emotional development of infants.

In the context of our current scientific understanding, cognitive and emotional brain functions involve coordinated activities of brain circuits that integrate molecular, cellular, synaptic and network signaling [5]. Hence, mental disorders may arise from dysfunction (failure) of crucial brain circuits. Both "normal" and aberrant brain functions originate from genetic risk and environmental influences, particularly during sensitive developmental periods when brain circuits are not fully mature [6]. Parents are the primary source of environment-derived sensory signals early in life, signals that are known to influence the maturation of brain circuits $[7,8]$. The question then arises whether smartphone use influences parental signals to the infant in a manner that might be detrimental to the maturation of brain circuits.

What do we know about parental signals, especially the salient characteristics of those parental signals that influence brain development? In humans, a robust body of literature supports parental availability, consistency, sensitivity and predictability as foundations for optimal cognitive and emotional development [9]. Research in humans might struggle with distinguishing the genetic contribution of a parent to a child from the contribution derived from parental signals during care and interaction with the infant; it is also difficult to infer causality in complex contexts with numerous potential confounders. Yet, in non-human primates and rodent systems, presence of maternal care signals and their quantity and quality have been shown to modulate neurodevelopmental processes, supporting causality and suggesting mechanisms [10,11]. The overall quantity, as well as many qualitative aspects of parental signals to the infant are unlikely to be fundamentally affected by the use of a smartphone. However, recent information suggests that other crucial aspects of parental signals might be profoundly affected.

There is now growing evidence in both humans and controlled experimental animal systems that, in addition to the parentalbehavior properties described above, the patterns of parental signals may impact cognitive and emotional outcomes through the modulation of the maturation of the underlying brain circuits [11-13]. Specifically, repeated, predictable parental-signal patterns promote resilience to stress and enhanced memory whereas fragmented and unpredictable patterns of parental signals might negatively impact these functions [11-14]. Whereas, as described above, the prospective human studies are by their nature associational, work in experimental systems, replicated widely [15-20], suggests causality. In experimental systems, predictable barrages of maternal care enhanced stress resilience via reduced excitatory synaptic innervation and epigenetic programming of stress-sensitive cells [21]. By contrast, fragmented and unpredictable maternal signals augmented excitatory input onto stresssensitive cells and influenced the maturation and function of a number of brain circuits, with consequent emotional and cognitive sequelae $[22,23]$.

We do not know if daily, rampant smartphone use significantly disrupts the predictability of a parent's signals to the infant or promotes their fragmentation. Also unclear is the age at which the developing brain is most sensitive to optimal and adverse parental signals. Whereas evidence exists that the first two years of life might be a particularly sensitive period [24], effects on older infants and pre-schoolers cannot be excluded. In addition, distinguishing parental smartphone use from the myriad other aspects of parent-child interaction will be a daunting task. Furthermore, the effects of smartphone use on parental signals needs to be considered in the context of the profound positive and negative effects of smartphone use on public health, such as

\footnotetext{
${ }^{1}$ Department of Anatomy/Neurobiology, University of California-Irvine, Irvine, CA 92697, USA; ${ }^{2}$ Department of Pediatrics, University of California-Irvine, Irvine, CA 92697, USA and ${ }^{3}$ Department of Neurology, University of California-Irvine, Irvine, CA 92697, USA

Correspondence: Tallie Z. Baram (tallie@uci.edu)
}

Received: 12 July 2018 Revised: 1 August 2018 Accepted: 6 August 2018

Published online: 21 August 2018 
enabling rapid access to health care versus promoting distractionrelated driving fatalities. Yet, in view of our emergent understanding of the role of sensory signals in the maturation of brain circuits and the overwhelming prevalence of parental interactions with devices, the potential consequences of parental phone use on the signals that reach and modulate the maturation of the infant brain merit consideration and study.

\section{ACKNOWLEDGEMENTS}

The authors' research has been supported by NIH grants MH73136, NS28912, and MH096889 and by the Hewitt Foundation for Biomedical Research.

\section{ADDITIONAL INFORMATION}

Competing interests: The authors declare no competing interests.

Publisher's note: Springer Nature remains neutral with regard to jurisdictional claims in published maps and institutional affiliations.

\section{REFERENCES}

1. Pew Research Center, Mobile Technology Fact Sheet. Accessed 3 July 2018.

2. Millennials are Top Smartphone users; Nielsen Newswire Reports, Nielson Company LLC. Accessed 3 July 2018.

3. Wiedemann P, Schütz H. Children's health and RF EMF exposure. Views from a risk assessment and risk communication perspective. Wien Med Wochenschr. 2011;161:226-32

4. Sudan M, Kheifets L, Arah OA, Olsen J. Cell phone exposures and hearing loss in children in the Danish national birth cohort. Paediatr Perinat Epidemiol. 2013;27:247-57.

5. Redish AD, Gordon JA. Computational psychiatry: new perspectives on mental illness. In: Lupp J editors. Strungmann forum reports, vol. 20. Cambridge, MA: MIT Press; 2016.

6. Bale TL, Baram TZ, Brown AS, Goldstein JM, Insel TR, McCarthy MM, Nemeroff CB, Reyes TM, Simerly RB, Susser ES, Nestler EJ. Early life programming and neurodevelopmental disorders. Biol Psychiatry. 2010;68:314-9.

7. Espinosa JS, Stryker MP. Development and plasticity of the primary visual cortex. Neuron. 2012;75:230-49.

8. Sevelinges Y, Sullivan RM, Messaoudi B, Mouly AM. Neonatal odor-shock conditioning alters the neural network involved in odor fear learning at adulthood. Learn Mem. 2008;15:649-56.

9. Sheridan MA, McLaughlin KA. Dimensions of early experience and neural development: deprivation and threat. Trends Cogn Sci. 2014;18:580-5.

10. Weaver IC, Cervoni N, Champagne FA, D'Alessio AC, Sharma S, Seckl JR, Dymov S, Szyf M, Meaney MJ. Epigenetic programming by maternal behavior. Nat Neurosci. 2004;7:847-54.
11. Baram TZ, Davis EP, Obenaus A, Sandman CA, Small SL, Solodkin A, Stern H. Fragmentation and unpredictability of early-life experience in mental disorders. Am J Psychiatry. 2012;169:907-15.

12. Davis EP, Stout SA, Molet J, Vegetabile B, Glynn LM, Sandman CA, Heins K, Stern $\mathrm{H}$, Baram TZ. Exposure to unpredictable maternal sensory signals influences cognitive development across species. PNAS . 2017;114:10390-5.

13. Molet J, Heins K, Zhuo X, Mei YT, Regev L, Baram TZ, Stern H. Fragmentation and high entropy of neonatal experience predict adolescent emotional outcome. TransI Psychiatry. 2016;6:e702.

14. Glynn LM, Howland MA, Sandman CA, Davis EP, Phelan M, Baram TZ, Stern HS. Prenatal maternal mood patterns predict child temperament and adolescent mental health. J Affect Disord. 2018:228:83-90.

15. Heun-Johnson $H$, Levitt $P$. Early-life stress paradigm transiently alters maternal behavior, Dam-Pup interactions, and offspring vocalizations in mice. Front Behav Neurosci. 2016;10:142.

16. Bath KG, Manzano-Nieves G, Goodwill H. Early life stress accelerates behavioral and neural maturation of the hippocampus in male mice. Horm Behav. 2016;82:64-71

17. Liao XM, Yang XD, Jia J, Li JT, Xie XM, Su YA, Schmidt MV, Si TM, Wang XD. Blockade of corticotropin-releasing hormone receptor 1 attenuates early-life stress-induced synaptic abnormalities in the neonatal hippocampus. Hippocampus. 2014:24:528-40.

18. Derks NA, Krugers HJ, Hoogenraad CC, Joëls M, Sarabdjitsingh RA. Effects of early life stress on synaptic plasticity in the developing hippocampus of male and female rats. PLoS ONE. 2016;11:e0164551 https://doi.org/10.1371/journal. pone. 0164551

19. Knop J, Joëls $M$, van der Veen R. The added value of rodent models in studying parental influence on offspring development: opportunities, limitations and future perspectives. Curr Opin Psychol. 2017;15:174-81.

20. Walker CD, Bath KG, Joels M, Korosi A, Larauche M, Lucassen PJ, Morris MJ, Raineki $C$, Roth TL, Sullivan RM, Taché Y, Baram TZ. Chronic early life stress induced by limited bedding and nesting (LBN) material in rodents: critical considerations of methodology, outcomes and translational potential. Stress. 2017;20:421-48.

21. Singh-Taylor A, Molet J, Jiang S, Korosi A, Bolton JL, Noam Y, Simeone K, Cope J, Chen Y, Mortazavi A, Baram TZ. NRSF-dependent epigenetic mechanisms in programming stress-sensitive neurons by neonatal experience, promoting resilience. Mol Psychiatry. 2018;23:648-57.

22. Gunn BG, Cunningham L, Cooper MA, Corteen NL, Seifi M, Swinny JD, Lambert JJ, Belelli D. Dysfunctional astrocytic and synaptic regulation of hypothalamic glutamatergic transmission in a mouse model of early-life adversity: relevance to neurosteroids and programming of the stress response. J Neurosci. 2013;33:19534-54.

23. Bolton JL, Molet J, Regev L, Chen Y, Rismanchi N, Haddad E, Yang DZ, Obenaus A, Baram TZ. Anhedonia following early-life adversity involves aberrant interaction of reward and anxiety circuits and is reversed by partial silencing of amygdala corticotropin-releasing hormone gene. Biol Psychiatry. 2018;83:137-47.

24. Nelson CA 3rd, Zeanah CH, Fox NA, Marshall PJ, Smyke AT, Guthrie D. Cognitive recovery in socially deprived young children: the Bucharest Early Intervention Project. Science. 2007;318:1937-40. 